JURNAL PENDIDIKAN, p-ISSN 2715-095X, e-ISSN 2686-5041

Volume 30, No.1, Maret 2021 (1-12)

Online: http://journal.univetbantara.ac.id/index.php/jp

\title{
Kelebihan dan Kekurangan Pembelajaran Luring dan Daring dalam Pencapaian Kompetensi Dasar Kurikulum Bahasa Arab di Madrasah Ibtidaiyah 2 Kabupaten Gorontalo
}

\author{
Thityn Ayu Nengrum, Najamuddin Petta Solong dan Muhammad Nur Iman \\ Institut Agama Islam Negeri Sultan Amai, Gorontalo, e-mail: thitynnengrum20@gmail.com. \\ uddinpettasolong@iaingorontalo.ac.id, muhnuriman@iaingorontalo.ac.id
}

\begin{abstract}
Abstrak: Artikel ini mengkaji tentang keleibihan dan kekurangan pembelajaran luring dan daring dalam pencapaian kompetensi dasar kurikulum bahasa Arab di Madrasah Ibtidaiyah 2 Kabupaten Gorontalo. Tujuan dari artikel ini adalah untuk mengetahui terkait apa saja yang menjadi kelebihan maupun kekurangan pada proses pembelajaran luring maupun daring. Seperti yang kita ketahui bahwa, ada dua system pembelajaran yang diterapkan saat ini yaitu system daring (dalam jaringan) dan system luring (luar jaringan). Tentu, kedua system pembelajaran ini, memiliki letak persamaan maupun berbedaan, dan juga letak kelebihan dan kelemahan baik dalam proses pembelajaran, maupun keefektifan yang akan dicapai, tentu hal ini juga akan berpengaruh pada pencapaian kompetensi dasar yang diterapkan. Penelitian ini menggunakan metode kualitatif dengan pendekatan deskriptif berdasarkan fakta lapangan untuk mengetahui kelebihan dan kekurangan pembelajaran luring maupun daring dalam pencapaian kompetensi dasar kurikulum bahasa Arab. Hasil kajian dan pembahasan menunjukan bahwa terdapat data yang diperoleh dilapangan bahwa pembelajaran luring maupun daring terdapat kelebihan dan kekurangan baik dari segi, metode, media, maupun proses pembelajarannya. Dan berkenaan dengan hal itu, proses pembelajaran luring maupun daring keduanya tidak menjamin kompetensi dasar dalam kurikulum, dapat sepenuhnya tercapai dengan maksimal.
\end{abstract}

Kata-kata Kunci: Luring dan Daring, Kompetensi Dasar, Kurikulum Bahasa Arab

\section{Strengths and Weaknesses of Offline and Online Learning In Achieving Basic Competencies of The Arabic Language Curriculum In Madrasah Ibtidaiyah 2 Gorontalo District}

Thityn Ayu Nengrum, Najamuddin Petta Solong dan Muhammad Nur Iman

Institut Agama Islam Negeri Sultan Amai, Gorontalo, e-mail: thitynnengrum20@gmail.com, uddinpettasolong@iaingorontalo.ac.id, muhnuriman@iaingorontalo.ac.id

\begin{abstract}
Abstrack: This article examines the strengths and shortcomings of offline and online learning in achieving the basic competencies of the Arabic language curriculum at Madrasah Ibtidaiyah 2, Gorontalo district. The purpose of this article is to find out what are the advantages and disadvantages of the offline and online learning process. As we know that, there are two learning systems that are currently being implemented, namely the online system (in the network) and the offline system (outside the network). Of course, these two learning system have similiarities and differences, as well as where the strengths and weaknesses are in the learning process, as well as the affectiveness to be achieved. of course this will also affect the achievement of basic competencies that are applied. This study used a qualitative method wirh
\end{abstract}


a descriptive approach based on field facts to determine the advantages and disadvantages of offline and online learning in achieving the basic competencies of the Arabic language curriculum. The result of the study and discussion show that there is data obtained in the field that offline and online learning have advantages and disadvantages both in terms of aspects, methods, media, and the learning process. And with regard to this, both offline and online learning processes do not guarantee basic competencies in the curriculum which can be fully achieved.

Keywords: Offline and Online, Basic Competencies, Arabic Language Curriculum

\section{Pendahuluan}

Dampak yang disebabkan covid-19 membuat keresahan diseluruh negara. Banyak bidang yang menerima pengaruh wabah tersebut, seperti pada bidang pendidikan. Dengan adanya Covid-19, pemerintah mengeluarkan Surat Edaran No. 4 tahun 2020 yang menyatakan bahwa system pembelajaran dilaksanakan dirumah (BDR). Wabah (Covid-19) telah terjadi di 219 negara di dunia, tentunya ini berdampak pada berbagai bidang khususnya bidang pendidikan. Untuk itu pemerintah menghimbau masyarakat untuk melakukan pembatasan social (social distancing) dan menjaga jarak fisik (physical distancing), memakai masker dan selalu cuci tangan. Pendidikan merupakan wadah penting yang dapat mempengaruhi potensi manusia dan menjadi tolak ukur kemajuan bangsa. Dengan adanya pendidikan manusia bias memantaskan potensi diri untuk bekal bereksistensi di dunia dan tentunya bermanfaat untuk dirinya, masyarakat, bangsa dan negara. Yang menjadi masalah pendidikan di Indonesia saat itu yaitu terletak pada persoalan pemerataan pendidikan. Hari ini masih ada beberapa kalangan masyarakat Indonesia yang belum memperoleh pendidikan yang layak, dan saat ini dunia sedang dilanda musibah, yaitu mewabahnya virus Covid-19. Virus covid-19 menekankan bagi setiap orang untuk menjaga jarak atau memenuhi protocol kesehatan agar dampaknya dapat tidak terjadi secara langsung. Salah satu korbannya adalah anak usia dini yang memiliki pengaruh besar bagi penguasaan ilmu karena proses pembelajaran berlangsung dirumah masing-masing. Pada abad ke-21, menekankan bahwa pembelajaran dilakukan secara daring. Menariknya ditengah wabah ini pasti akan berdampak pada segala aspek kehidupan khususnya pada pendidikan anak usia dini. Sehingga peran orang tua menjadi kunci utama dalam pembelajaran anak sehingga minat belajar anak tidak menurun meskipun proses pembelajaran tidak dilangsungkan dengan tatap muka. Pada era sekarang membuktikan bahwa system pembelajaran seakan berubah, dari yang dulunya anak-anak merasakan suasana kelas, bermain bersama teman-teman, bertatap muka langsung dengan guru, hingga sekarang tidak bias seperti itu lagi karena akibat virus covid-19. Dengan itu pemerintah menyatakan kebijakan, dengan mewajibkan pembelajaran online atau daring di semua jenjang Pendidikan. Kebijakan tersebut difokuskan untuk lembaga-lembaga pendidikan yang ada di pusat maupun daerah. Kebijakan itu menjadi solusi efektif digunakan agar antar sesame manusia tidak saling berinteraksi satu sama lain, bahkan hanya menggunakan berbagai media. Pengaruh Covid-19 terbesar yang dirasakan oleh dunia Pendidikan di Indonesia adalah adanya kebijakan untuk merubah system pembelajaran dari normal tatap muka menjadi daring (dalam jaringan). Kebijakan tersebut merupakan implementasi dari 
surat Edaran Mendikbud Nomor 3 tahun 2020 tentang pencegahan Covid-19 pada satuan Pendidikan, dan surat Edaran Nomor 4 tahun 2020 tentang pelaksanaan kebijakan Pendidikan dalam masa darurat penyebaran Coronavirus Dease (Covid-19).Pembelajaran daring sudah diterapkan diseluruh dunia, hanya saja pengaplikasiaanya dilakukan secara bertahap (Sun et al., 2020). Dalam pembelajaran daring (dalam jaringan) dilakukan dengan system proses pembelajarannya harus ada media pendukung seperti, Group WhatsApp, Zoom, dan media lainnya. Untuk itu diperlukan strategi-strategi khusus agar dapat menghargai sebagai individu social yang sedang tumbuh kembang. Masalah yang ditemui sekarang yaitu pembelajaran daring mulai dikeluhkan bagi sector Pendidikan, para pendidik, siswa, dan orang tua. Oleh karena itu, disarankan untuk menyeimbangkan antara pembelajaran baik daring maupun luring.

Bahwasanya pembelajaran daring dikatakan salah satu solusi dalam memecahkan masalah pendidikan terkait penyelenggaraan pembelajaran. Istilah pembelajaran daring adalah metode belajar yang menggunakan model belajar yang menggunakan model interaktif berbasis internet dan learning manajemen system (LMS). Sedangkan luring menurut Sunendar, bahwa luring diistilahkan dengan akronim dari "luar jaringan", Misalnya belajar melalui buku pegangan siswa atau pertemuan tatap muka. Tentunya bagi sebagai seorang pendidik haruslah diperlukan penguasaan kompetensi pada keduaproses pembelajaran tersebut. Sehingga akan tercapai fungsi dan tujuan Pendidikan sesuai kebutuhan masyarakat dan tuntunan keadaan zaman. Dalam KMA 183 tahun 2019 (Kemenag RI, 2019:11) menegaskan bahwa kurikulum PAI dan bahasa Arab dirancang untuk mengembangkan keseimbang anantara sikap spiritual dan social, pengetahuan dan keterampilan, serta penerapan yang dilakukan di madrasah harus berdasarkan evaluasi tentunya pada pembelajaran bahasa Arab agar tercapai nilai dari empat keterampilan tersebut. Pada masa ini, pembelajaran untuk semua mata pelajaran memiliki desain yang berbeda khususnya pembelajaran bahasa Arab. Pembelajaran yang biasanya didesain dan dilaksanakan di dalam ruangan kelas, kini diganti dalam via daring, tanpa tatap muka. Pembelajaran dilaksanakan dengan berbagai media pendukung. Dapat dipastikan, bahwa pembelajaran menggunakan media virtual memiliki banyak keterbatasan. Selain itu, lama pembelajaran juga dikurangi. Sehingganya, keadaan seperti ini, sangat minim menjadikan guru lebih fokus pada usaha dalam penuntasan materi pembelajaran sesuai pencapaian kurikulum. Dengan ini guru kemudian condong hanya menyampaikan materi pembelajaran dan kurang meninjau penguasaan kompetensi peserta didik, padahal kompetensi baik kognitif maupun afektif haruslah di kuatkan bukan malah diabaikan. Di Indonesia Pendidikan semakin mengalami perkembangan yang signifikan terutama pada masalah tekhnologi, keadaan hari ini menjadikan pendidikan di Indonesia mengalami penurunan dalam kualitas pembelajarannya, dua system pembelajaran saat ini sudah diterapkan baik daring maupun luring. Akan tetapi, untuk saat ini system daring yang diterapkan. Pembelajaran daring menjadikan tekhnologi cenderung berkembang. Pada pembelajaran bahasa sendiri tentunya harus tercipta pembelajaran yang berbeda dengan pendukung media agar tercapai tujuan pembelajaran. Sejalan dengan perkembangan era digital yang didukung oleh tekhnologi informasi dan komunikasi (TIK), sehingga pemanfaatan tekhnologi menjadi suatu keniscayaan dalam keefektifan pembelajaran. Penelitian ini bertujuan untuk mencari tahu apa saja yang menjadi kelebihan dan kekurangan pembelajaran luring maupun daring dalam pencapaian kompetensi dasar kurikulum bahasa Arab di Madrasah Ibtidaiyah Negeri 2 Kabupaten Gorontalo. Sistem pembelajaran yang diterapkan ada dua yaitu system daring dan luring, oleh karena itu pasti terdapat letak kelebihan maupun kelemahan dari dua 
system tersebut baik dari segi pelaksanaan pembelajaran, metode, maupun media yang digunakan. Berdasarkan hasil penelitian tingkat kenyamanan siswa hanya sebesar 59,21\% menyatakan nyaman, sedangkan sisanya $40,79 \%$ merasa tidak nyaman dengan pembelajaran daring. Kombinasi antara pembelajaran luring dan daring kita kenal dengan istilah Blended learning, dari kombinasi tersebut akan membuat siswa tertarik dalam mengikuti pembelajaran yang berlangsung dan tentunya guru sudah mempersiapkan hal-hal yang berkaitan dengan kompetensi dasar yang akan dicapai. Pola pembelajaran antara daring maupun luring memilki kompetensi dasar berbeda dalam pencapaian kurikulum bahasa Arab baik dari segi pelaksanaan pembelajaran, media, maupun metode yang digunakan. Keberhasilan dalam mencapai tujuan tersebut tidak terlepas dalam kemampuan seorang guru dalam menyiapkan strategi pembelajaran yang tepat. Kemantapan persiapan metode, model, dan media pembelajaran menjadi salah satu faktor utama yang dapat membantu meningkatkan hasil belajar. Dengan demikian untuk mencapai tujuan pembelajaran bahasa Arab di masa pembelajaran daring ini, haruslah ada pemilihan strategi pembelajaran oleh guru dengan memperhatikan karakteristik dan kebutuhan siswa sesuai dengan materi yang terkait, serta sangat diperlukan adanya strategi pembelajaran yang disusun sistematis dan menarik, sehingga dapat mencapai kompetensi yang diharapkan.

\section{Metode Penelitian}

Jenis penelitian ini menggunakan jenis penelitian kualitatif, atas dasar perspektif partsipan atau narasumber dalam pemerolehan data tersebut. Pendekatan yang digunakan adalah system pencarian data yang dikembangkan dengan analisis dan dituangkan dalam bentuk kata-kata, atau kalimat bukan bernominal angka (Nawawi, 2002: 63). Metode penelitian ini lebih menitik beratkan pada data hasil penelitian yang didapatkan. Metode ini, didapatkan data berupa deskripsi dari responden dan berupa catatan lapangan. Sampel dalam penelitian ini adalah lingkungan sekolah MIN 2 Kabupaten baik guru maupun siswa menjadi sasaran dalam penelitian ini, dan populasinya hanya menitik beratkan pada guru mata pelajaran bahasa Arab. Mengenai metode atau instrumen yang digunakan yaitu dengan cara melakukan observasi dan wawancara terbuka. Sedangkan teknik analisis, dilakukan dengan cara menelaah hasil dari observasi dan wawancara yang telah dilakukan.

Teknik observasi dilakukan peneliti untuk mendapatkan informasi terkait keadaan sekolah dan tentunya pada system pembelajarannya. Seperti yang kita ketahui bersama bahwa proses pembelajaran dimasa pendemi seperti sekarang ini berbeda. Siswa yang dulunya bersekolah normal, kini harus bersekolah system daring (dalam jaringan), dan tidak menutup kemungkinan para guru pun melakukan system luring (luar jaringan). Sehingga hal tersebut menjadi observasi bagi peniliti. Selanjutnya tekhnik wawancara dilakukan peneliti untuk mendapatkan data dari guru terutama pada guru mata pelajaran bahasa Arab, informasi yang diterima peneliti berupa perencanaan, persiapan, dan pelaksanaan pembelajaran selama proses daring maupun luring yang diterapkan oleh guru tersebut. Data-data terkait dengan system pembelajaran luring maupun daring dan juga terkait dengan kompetensi dasar dalam kurikulum bahasa Arab tersebut didapat dengan menggunakan pendekatan analisis deskriptif kualitatif, maksudnya bahwa hal-hal khusus 
yang berhasil ditemukan dalam penelitian dikumpulkan bersama-sama lalu dikumpulkan abtraksinya.

\section{Hasil Penelitian}

Berdasarkan hasil yang diperoleh dilapangan melalui observasi dan lembar wawancara peneliti mendapatkan data terkait bahwasanya terdapat sisi kelebihan dan kekurangan pembelajaran luring dan daring dalam pencapaian kompetensi dasar kurikulum bahasa Arab di Madrasah Ibtidaiyah Negeri 2 Kabupaten Gorontalo. Hasil observasi menunjukan bahwa pelaksanaan pembelajaran yang ada di sekolah tersebut menggunakan system daring maupun luring. Mengenai wawancara ada beberapa pertanyaan yang diajukan peneliti kepada responden untuk menunjang hasil penelitian ini. Wawancara dengan guru mata pelajaran bahasa Arab telah peneliti lakukan. Dari sini peneliti mengajukan pertanyaan yaitu berkaitan dengan proses pembelajaran selama masa pendemi, persamaan dan perbedaan pelaksanaan pembelajaran, sisi kelebihan dan kekurangan keduanya, dan juga implementasinya pada pencapaian kompetensi dasar dalam kurikulum bahasa Arab. Hasil wawancara menyatakan bahwa, pelaksanaan pembelajaran yang ada di MIN 2 Kabupaten Gorontalo menerapkan system pembelajaran daring dan luring untuk semua mata pelajaran tidak hanya bahasa Arab, dan pelaksanaan pembelajarannya melalui media group WhatsApp, mengenai keefektifannya bahwa keduanya kurang efektif dilakukan karena jika menerapkan daring materi yang disampaikan hanya terbatas tidak mencakup semua kompetensi begitupun dengan proses luring materi yang disampaikan bisa mencakup semua kompetensi hanya saja siswa pada saat luring hanya dibatasi untuk ikut serta. Mengenai letak persamaan dan perbedaan dari kedua system pembelajaran ini bahwasannya keduanya memiliki persamaan dan perbedaan.

Tabel 1. Persamaan dan perbedaan proses pembelajaran luring dan daring

\begin{tabular}{|c|c|c|}
\hline Aspek yang diamati & Luring & Daring \\
\hline \multirow[t]{2}{*}{ Media Pembelajaran } & \multicolumn{2}{|c|}{ Perbedaan } \\
\hline & $\begin{array}{l}\text { Guru menggunakan spidol } \\
\text { dan papan tulis dalam } \\
\text { menjelaskan. }\end{array}$ & $\begin{array}{l}\text { Guru menggunakan } \\
\text { media/aplikasi penunjang dalam } \\
\text { pembelajaran seperti, zoom, } \\
\text { group WhatsApp, E-learning,. }\end{array}$ \\
\hline Bahan Ajar & \multicolumn{2}{|r|}{ Persamaan } \\
\hline \multirow{3}{*}{ Model Pembelajaran } & \multicolumn{2}{|c|}{$\begin{array}{l}\text { Guru menggunakan bahan ajar buku bahasa Arab Madrasah } \\
\text { Ibtidaiyah dalam pemberian materi. }\end{array}$} \\
\hline & \multicolumn{2}{|c|}{ Perbedaan } \\
\hline & $\begin{array}{lcr}\text { Guru menjelaskan materi } \\
\text { secara langsung } & \text { (tatap } \\
\text { muka). } & & \end{array}$ & $\begin{array}{l}\text { Guru membuat video penjelasan } \\
\text { materi kemudian dikirim kepada } \\
\text { siswa melalui via Group } \\
\text { WhatsApp. }\end{array}$ \\
\hline
\end{tabular}

Keefektivan

Persamaan

Pembelajaran 


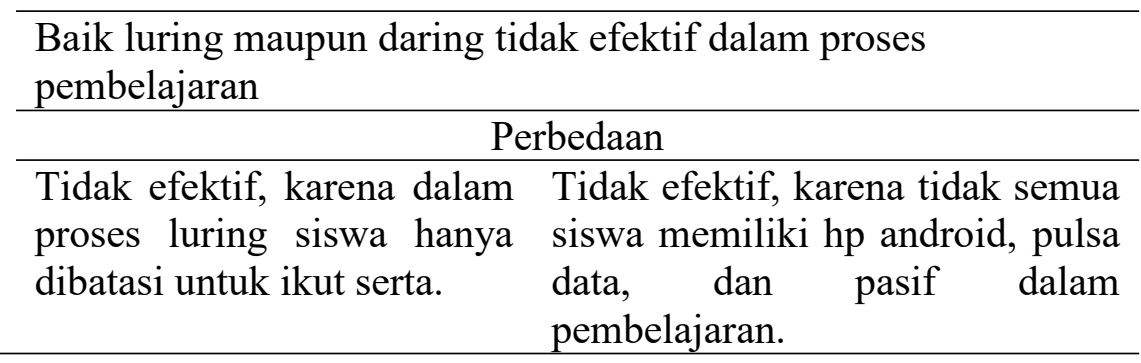

Letak persamaan antara pembelajaran daring dan luring yaitu dalam pemberian materi/bahan ajar yang disampaikan sama, yang membedakan yaitu pada media dan model pelaksanaannya seperti pemberian penjelasan materi serta tugas-tugas. Terkait dengan proses pembelajaran luring maupun daring, peneliti akan menampilkan hasil pengamatan terkait dengan persamaan dan perbedaan antara pembelajaran luring maupun daring dalam bentuk Tabel 1.

Hasil-hasil yang diperoleh terkait dengan persamaan dan perbedaan proses pembelajaran luring dan daring menunjukan adanya hasil spesifik pada perbandingan antara proses luring maupun daring. Pada pengamatan diatas tampak secara umum dalam proses pembelajaran dimasa pandemic baik luring maupun daring kedua memiliki aspek-aspek yang berbeda maupun sama, hal ini juga akan berpengaruh pada keefektivan dalam proses pembelajaran zaman sekarang. Hal ini juga diakui oleh guru mata pelajaran bahasa Arab, bahwa pembelajaran luring (tatap muka) sangat jarang untuk dilakukan karena, akan sama saja jika akan mengajar proses luring, guru pun akan tetap mempersiapkan video pembelajaran yang akan dilakukan pada saat daring. Pernyataan yang berbeda dari peserta didik, bahwa mereka ingin belajar pada proses luring karena dari sini mereka tidak akan merasa bosan dan jenuh dalam menerima pembelajaran. Untuk menguatkan hasil penelusuran diatas, peneliti juga melakukan pengumpulan data observasi dan wawancara yang diajukan kepada guru mata pelajaran terkait sisi kelebihan dan kekurangan pada pembelajaran luring maupun daring, berikut disajikan dalam bentuk Tabel 2 .

Tabel 2. Kelebihan dan kekurangan pembelajaran luring dan daring

\begin{tabular}{|c|c|c|c|}
\hline No & $\begin{array}{c}\text { Proses } \\
\text { pembelajaran }\end{array}$ & Kelebihan & Kekurangan \\
\hline 1. & Daring & $\begin{array}{l}\text { Materi yang sudah } \\
\text { diajarkan masih } \\
\text { bisa diberikan } \\
\text { kembali }\end{array}$ & $\begin{array}{ll}\text { - } & \text { Siswa tidak efektif } \\
\text { - } & \text { Tidak semua orang tua siswa } \\
\text { memiliki data/Hp } \\
\text { - } & \text { Pemberian materi tidak efektif }\end{array}$ \\
\hline 2. & Luring & $\begin{array}{ll}\text { - } & \text { Siswa efektif dan } \\
\text { antusias } \\
\text { - } \\
\text { Pemberian materi } \\
\text { menyeluruh }\end{array}$ & $\begin{array}{ll}\text { - } & \text { Tidak semua siswa bisa ikut } \\
\text { luring karena hanya dibatasi } \\
\text { - } & \text { Fasilitas pembelajaran kurang } \\
\text { memadai }\end{array}$ \\
\hline
\end{tabular}


Berdasarkan hasil pengamatan diatas bahwa, baik pembelajaran daring dan luring keduanya memiliki sisi kelebihan dan kekurangan masing-masing. Bisa dikatakan system pembelajaran baru diciptakan sebagai pelengkap system sebelumnya. Saat ini pendidikan tidak hanya dibebankan pada lembaga sekolah, maupun guru selaku pendidik, namun harus ada peran dari orang tua dalam pendampingan anak dalam proses belajar. Dalam pembelajaran daring tidak dibutuhkan fisik seperti ruang kelas, karena dimanasaja bisa diadakan pembelajaran. Sedangkan system luring harus ada jarak yang dekat untuk menumbuhkan kualitas pembelajaran.

Tabel 3. Pencapaian Kompetensi Dasar dalam Kurikulum Bahasa Arab pada pembelajaran luring maupun daring

Sistem Pembelajaran Kompetensi Dasar (KD)

Daring $\begin{aligned} & \text { Mendeskripsikan tindak sosial dan unsur tutur bahasa } \\ & \text { (bunyi, kata, dan frasa) }\end{aligned}$
(1.1.

Luring

1.1. Menyatakan tutur bahasa dengan mengekspresikan secara lisan rasa cinta terhadap bahasa Arab.

1.2. Menyajikan hasil analisis bunyi dan kata sederhana terkait tema: العربية اللغة أحب secara lisan dan tulisan.

Dari kompetensi dasar (KD) yang disajikan dapat dilihat bahwa ada perbandingan yang signifikan dalam proses pembelajaran baik daring maupun luring. Tentunya hal ini akan berpengaruh pada proses dan hasil belajar yang dicapai oleh siswa. Berikut perbandingan proses belajar dan hasil belajar siswa dengan penerapan kompetensi dasar (KD) antara dua sistem pembelajaran baik daring maupun luring, disajikan dalam bentuk tabel:

Tabel 4. Pencapaian KD pada Proses Pembelajaran Daring dan Luring

Kompetensi Dasar (KD) Proses pembelajaran Hasil pembelajaran

\begin{tabular}{|c|c|}
\hline $\begin{array}{l}\text { 1.1. Memahami fungsi sosial } \\
\text { dan unsur kebahasaan } \\
\text { (bunyi, katadan makna) } \\
\text { dari teks sangat } \\
\text { sederhana terkait tema: العربية اللغة yang } \\
\text { melibatkan tindaktutur } \\
\text { mengekspresikan rasa } \\
\text { cinta terhadap bahasa } \\
\text { Arab. } \\
\text { 1.2Menganalisis unsur } \\
\text { kebahasaan (bunyi, kata } \\
\text { dan makna) dari teks } \\
\text { sangat sederhana terkait }\end{array}$ & $\begin{array}{l}\text { Kurang efektif. Karena jika } \\
\text { dilihat KD tidak terpenuhi, } \\
\text { sehingga } \\
\text { pembelajaran }\end{array}$ \\
\hline
\end{tabular}




\begin{tabular}{|c|c|}
\hline $\begin{array}{l}\text { tema: اللغة العربيةdengan } \\
\text { memperhatikan struktu } \\
\text { الحبر فحل و المضارع الفعل }\end{array}$ & kepada siswa melalui daring. \\
\hline $\begin{array}{l}\text { 1.1. Mendemonstrasikan } \\
\text { tindak tutur } \\
\text { mengekspresikan rasa } \\
\text { cinta terhadap bahasa } \\
\text { Arab secara lisan . } \\
\text { 1.2. Menyajikan hasil } \\
\text { analisis bunyi dan kata } \\
\text { sederhana terkait tema: } \\
\text { العربية secara } \\
\text { lisan dan tulisan. }\end{array}$ & \begin{tabular}{lrlr} 
Proses & \multicolumn{2}{c}{ pembelajaran } & Kurang efektif. Karena jika \\
dilakukan secara luring (off & dilihat KD tidak terpenuhi, \\
line). Proses luring & sehingga & proses \\
dilaksanakan disalah satu & pembelajaran & tidak \\
rumah siswa. & Guru & maksimal, karena pada \\
memberikan materi & sesuai & proses luring hanya dibatasi \\
tema kepada & siswa, & siswa untuk ikut serta. \\
kemudian meminta & siswa & \\
untuk menghafal & dan & \\
mendemonstrasikan secara & & \\
pribadi. & &
\end{tabular} \\
\hline
\end{tabular}

Selanjutnya, berdasarkan dengan hasil data yang telah didapat bahwa, dimana proses pembelajaran daring dan luring dalam pencapaian kompetensi dasar kurikulum bahasa Arab tidak sepenuhnya terpenuhi, hal ini dikarenakan ada beberapa kompetensi dasar (KD) yang mengharuskan atau melibatkan langsung siswa dalam bertutur kata seperti, mufradat siswa harus diminta untuk menyebutkannya, dan terutama pada materi tentang hiwar siswa harus mampu untuk mendialogkan itu. Kondisi saat ini menjadikan pembelajaran yang dulunya tatap muka kini seolah berganti dengan pembelajaran proses dirumah, dengan ini terdapat beberapa kompetensi dasar yang tidak bisa mengukur nilai kognitif dan afektif siswa, dengan demikian kompetensi dasar pada kurikulum bahasa Arab tidak tercapai.

\section{Pembahasan}

Dengan hadirnya Covid-19 membuat keresahan pada jalan hidup masyarakat di dunia terutama pendidikan (Rachmawati, 2020). Adanya pandemic Covid-19 membuat sekolah yang biasanya tatap muka dikonversi dengan system daring. Untuk itu pembelajaran daring menjadi salah satu alternatif dalam mengatasi permasalahan tersebut. Guru dan peserta didik harus melakukan adaptasi dengan mengubah pendidikan tatap muka tradisional (luring) kependidikan daring atau pendidikan jarak jauh. Aplikasi pendukung pembelajaran ini yaitu seperti WhatsApp, Zoom, Google Classroom, Zenius, Quipper, dan Microsoft(Kumar \& Nanda, 2018). Dalam penerapan kedua proses pembelajaran ini tentulah terdapat beberapa kendala seperti terbatasnya waktu pembelajar karena waktu pembelajaran di kurangi sehingga materi yang disampaikan tidak maksimal. Terdapat kelemahan pada pembelajaran ini seperti minimmnya jaringan atau kuota internet (Risdianto dkk, 2020). Di masa pandemi Covid-19 ini sekolah menggunakan berbagai cara agar pembelajaran tetap berjalan seperti menggunakan pembelajaran daring terlebih dahulu dengan menggunakan media social seperti apikasi WhatsApp, Google Classroom, Google 
Meet, Edmodo dan Zoom. Agar dalam proses pembelajaran bisa berjalan lancar guru harus mengarahkan pembelajaran terlebih dahulu. Biasanya dalam proses daring akan ditemukan siswa yang tidak mengerjakan tugas dengan alasan tidak memiliki fasilitas tekhnologi yang mendukung seperti smartphone dikarenakan orang tua dari siswa tersebut berstatus kurang mampu, bahkan untuk kebutuhan sehari-hari mereka merasa kekurangan. Dengan adanya kendala tersebut sekolah mencoba menggunakan pembelajaran luring dengan tatap muka akan tetapi siswa dibatasi untuk hadir dari satu kelas yang berjumlah 40 siswa jadi hanya 20 siswa yang hadir yang dibagi berdasarkan ganjil dan genap menurut absen. Dalam proses pembelajaran ini waktu pembelajaran juga di batasi satu jam pelajaran hanya 23 menit atau 30 menit, sekolah juga tidak memaksakan siswanya untuk memilih pembelajaran luring dari pada pembelajaran daring. Oleh karena itu, bisa dipresentasikan hasilnya yaitu sekitar 98\%. Pembelajaran daring dilaksanakan guru dengan menggunakan whatsApp sebagai media dalam menyampaikan materi atau mengirimkan tugas kepada peserta didik. Dewi (2020: 4) bisa dikatakan bahwa belajar daring dapat menggunakan menggunakan sistem tekhnologi, dan juga pemberian tugas harus melalui pemantauan atau pendampingan orang tua melalui media whatsApp grup sehingga bisa dipastikan bahwa anak benar-benar belajar. Guru juga harus berkoordinasi dengan orang tua, dalam memantau kegiatan belajar anak di rumah yaitu untuk memastikan adanya interaksi antara guru dengan orang tua. Dampak Pembelajaran daring bagi peserta didik sangat signifikan yaitu seperti mereka merasakan kejenuhan pada saat pembelajaran. Menurut Purwantoet al. (2020:6) akibat dari Covid-19 ini menyebabkan sekolah diliburkan dengan waktu yang cukup lama, sehingga membuat keresahan baik bagi peserta didik maupun guru.

Untuk mengatasi hal tersebut, guru berinisiatif untuk membuat media pembelajaran yang menarik seperti video, bahkan kebanyakan guru juga mengalami kendala atau keterbatasan dalam menggunakan media pembelajaran. Proses penilaian yang dilakukan oleh guru juga memiliki system yang sama dengan system penilaian pembelajaran yang biasanya ,penilaian yang diberikan guru dalam pembelajaran daring nilai juga diberikan langsung saat selesai pembelajaran dan dijanjikan semua peserta didik akan mendapat catatan nilai yang sama dari guru. Dan bisa dikatakan bahwa pembelajaran daring yang dilakukan untuk anak-anak sekolah dasar dirasa kurang efektif, jika dipresentasikan keefektifannya hanya sekitar $70 \%$. Dengan ini guru dan orang tua saling berkolaborasi untuk dapat memberikan motivasi kepada peserta didik dengan cara memberikan tugas yang menarik dan menyenangkan serta seluruh guru membuat sebuah video untuk memberikan energi semangat sekaligus motivasi bagi peserta didik walau melakukan pembelajaran di rumah saja. Adapun yang memiliki peran dalam proses pelaksanaan daring yaitu sebagai berikut: (1) Kepala sekolah, tugasnya memberikan surat tugas kepada guru untuk melakukan kegiatan pembelajaran di rumah sesuai dengan kelas atau mata pelajaran yang diampu guru melalui berbagai media online, serta melaporkan hasil kegiatan belajar di rumah kepada dinas pendidikan. (2) Guru, tugasnya menentukan media belajar yang sesuai dengan kondisi siswa agar belajar di rumah dapat berjalan secara efektif dengan pendukung media interaktif. (3) Siswa, tugasnya yaitu mempelajari bahan atau materi mata yang telah diberikan oleh guru. (4) Orang tua, tugasnya yaitu membantu anak pada proses pembelajaran berlangsung.

Uraian di atas, memberikan gambaran bahwa pembelajaran daring dapat berjalan sesuai kondisi yang dialami dengan berbagai permasalahan yang muncul baik yang sederhana maupun kompleks. Setiap permasalahan yang dihadapi dapat diselesaikan dengan menghadirkan beragam solusi dari para guru sehingga pembelajaran di masa 
pandemi covid-19 tetap berlangsung, yang penting anak tetap belajar dan terus belajar meskipun BDR. Dalam sistem pembelajaran, guru harus berperan lebih pada proses pengelolaan system pendidikan mulai dari proses perencanaan bahkan sampai tahap pelaksanaan pembelajaran di kelas. Salah satu proses pembelajaranyaitupembelajaran luring. Pembelajaran luring dapat menggunakan media buku, modul, dan bahan ajar dilingkungan sekitar Lembaga, bisa dengan media televisi, radio daerah dan lain sebagaianya.

Pembelajaran luring diistilahkan dengan pembelajaran offline, artinya pembelajaran ini dilaksanakan di rumah-rumah siswa. Tentunya hal ini menjadikan guru untuk lebih semangat dalam menyajikan materi yang lebih kreatif dan juga inovatif. Pembelajaran dengan metode ini dilaksanakan dengan teratur dan memenuhi protocol kesehatan tentunya proses pembelajaran sangat dibatasi untuk siswa bisa hadir pada proses pembelajaran berlangsung (Kemendikbud, 2020). Masyarakat Indonesia mengalami perubahan yang sangat cepat dan dalam dimensi yang beragam terkait dengan kehidupan individual, masyarakat, bangsa, dan umat manusia. Fenomena globalisasi yang membuat batas-batas fisik (teritorial) negara dan bangsa dipertajam dan dipercepat oleh kemajuan teknologi, terutama tekhnologi informasi dan komunikasi, sehingga mengharuskan adanya perubahan dan penyempurnaan kurikulum. Sejak Indonesia merdeka tahun 1945 kurikulum pendidikan terus menerus mengalami penyempurnaan mulaitahun 1947, tahun 1964, tahun 1968, tahun 1975, tahun 1984, tahun 1994, tahun 2004 (KBK), tahun 2006 (KTSP), dan tahun 2013 (K-13). Kurikulum adalah sebuah kerangka pendidikan yang dirancang dengan menggunakan pedoman untuk mencapai tujuan dari pendidikan. Dari definisi kedua dimensi tersebut, bahwasanya kurikulum memiliki pondasi untuk berdiri yaitu didukung dengan adanya tujuan, isi, dan materi sebagai bahan ajar pada suatu jenjang pendidikan. Kompetensi inti (KI) dan kompetensi Dasar (KD) dalam pembelajaran bahasa Arab, masih dirumitkan pada persoalan pergantian atau peralihan kurikulum 13, kini menjadi kurikulum atau KMA 183 dan 184. Implementasi pada kurikulum baru ini, tentunya pembelajaran bahasa Arab tidak menitik beratkan pada persoalan kaidah/qowaid saja tetapi bagaimana peserta didik bisa mengaplikasikan keterampilan berbicara bahasa Arab. Dan tentunya jika dilihat keadaan saat ini, bahwa komponen yang ditoreh pada KMA 183 kurang efektif jika diajarkan kepada peserta didik. Dengan demikian bahwa, pencapaian KD dalam kedua system pembelajaran memiliki dampak berbeda dan pastinya akan menoreh hasil yang kurang maksimal, sehingga peran guru dan orang tua harus diperkuat kembali untuk bisa berkolaborasi agar tercapai kompetensi pembelajaran baik itu system daring maupun luring.

\section{Simpulan dan Saran}

Pembelajaran baik daring maupun luring sepenuhnya harus dilakukan saat ini .Sebab, tidak mungkin peserta didik dibiarkan saja libur panjang hingga menunggu Covid-19 akan hilang. Dalam pembelajaran di masa pandemi Covid-19 ini di sekolah ini menggunakan berbagai cara supaya pembelajaran tetap berjalan seperti menggunakan pembelajaran daring terlebih dahulu dengan menggunakan media social seperti apikasi WhatsApp, Google Classroom, Google Meet, Edmodo dan Zoom. Supaya dalam proses pembelajaran bisa berjalan lancar guru harus memandu pembelajaran terlebih dahulu, 
dalam pembelajaran daring sebenarnya siswa lebih menyukai karena pembelajaran lebih menarik, membuat siswa menjadi penasaran dalam prosesnya membuat siswa menjadi aktif. Akan tetapi terkadang menemukan kendala seperti terdapatnya siswa yang tidak mengerjakan tugas dengan alasan tidak memiliki fasilitas tekhnologi yang mendukung seperti smartphone dikarenakan orang tua dari siswa tersebut tidak mampu membelikan atau di rumahnya hanya ada satu sehingga bergantian dengan keluarganya yang lain, tidak adanya sinyal di tempat mereka tingal, dan tidak adanya pulsa yang memadai.

Hasil dari penelitian ini mengacu pada tujuan yang dilakukan oleh peneliti. Peneliti melakukan studi komparasi antara proses pembelajaran daring dan luring dalam pencapaian kompetensi dasar kurikulum bahasa Arab, mengenai kurikulum dimasa pandemic sekarang di sekolah, khususnya mata pelajaran bahasa Arab itu sendiri mengikuti pedoman dari kurikulum baru yaitu pedoman KMA 183 2019. Tentunya ranah pembelajaran harus mengikuti kompetensi dasar yang sudah ada. Dalam hal ini, sesuai hasil observasi dan wawancara yang telah dilakukan, peneliti mencoba mencari temuan baru terkait persamaan maupun perbedaan dalam proses pembelajaran daring maupun luring dan juga mengenai kompetensi dasar dalam kurikulum yang diterapkan guru pada saat mengajar. Hal tersebut mendapat hasil bahwa terdapat perbandingan yang signifikan antara kedua pembelajaran tersebut, mulai dari metode, media, dan kegiatan selama pengajaran, dan mengenai kompetensi dasar (KD) baik untuk daring maupun luring kedunya tidak sepenuhnya terpenuhi.

\section{Daftar Rujukan}

Ahmad. (2020). Peningkatan Kompetensi Pedagogik Guru Dalam Pembelajaran Jarak Jauh Melalui Pendampingan Sistem Daring, Luring, atau Kombinasi Pada Masa New Normal Covid-19, Jurnal Paedagogy volume7(2), Oktober.

Atik Sholihatul, Hikmawati. (2020). Efektivitas Model Pembelajaran Daring Dalam Perkuliahan Bahasa Arab Di Institut Agama Islam Sunan Kalijogo Malang, Jurnal Muhadasah: Jurnal Pendidikan Bahasa Arab, volume 2(1), Juni.

Asmuni, (2020). Problematika Pembelajaran Daring di Masa Pandemi Covid-19 dan Solusi Pemecahannya, Jurnal Paedagogy: Jurnal Penelitian dan Pengembangan Pendidikan volume 7(4), Oktober.

Ekantini, Anita. (2020). EfektivitasPembelajaran Daring pada Mata Pelajaran IPA di Masa Pandemi Covid-19: Studi Komparasi Pembelajaran Luring dan Daring pada Mata Pelajaran IPA SMP, Jurnal Pendidikan Madrasah, volume 5(2), November.

Erwan Rio, Pratama dan Sri Mulyati. (2020). Pembelajaran Daring dan Luring Pada Masa Pandemi Covid-19, JurnalGagasan Pendidikan Indonesia, volume 1(2), Desember.

Giyarsi, (2020). Strategi Alternatif Dalam Pembelajaran Daring Pendidikan Agama Islam Pada Masa Pandemi Covid-19, Jurnal Ghaitsa: Islamic Education Journal volume 1(3).

Hanifah Unik Salsabila dkk. (2020). Peran Tekhnologi Dalam Pembelajaran Di Masa Pandemi Covid-19, Jurnal Al-Mutharahah: Jurnal Penelitian dan Kajian Sosial Keagamaan, volume 17(2), Juli-Desember.

Munir Ahmad, Saifulloh dan Mohammad Darwis. (2020). Manajemen Pembelajaran Dalam Meningkatkan Efektivitas Proses Relajar Mengajar Di Masa Pandemi Covid19, Jurnal Bidayatuna, volume 3(2), Oktober. 
Menteri Peraturan Agama Republik Indonesia Nomor 000912 Tahun 2013 Tentang Kurikulum Madrasah 2013 Mata Pelajaran Pendidikan Agama Islam Dan Bahasa Arab.

Menteri Keputusan Agama Nomor 183 Tahun 2019 Tentang Kurikulum PAI dan Bahasa Arab Pada Madrasah.

Malyana, Andasia. (2020). Pelaksanaan Pembelajaran Daring Dan Luring Dengan Metode Bimbingan Berkelanjutan Pada Guru Sekolah Dasar di Teluk Betung Utara Bandar Lampung. Jurnal Pedagogia: Jurnal Ilmiah Pendidikan Dasar Indonesia, volume 2(1).

Muslimah, Muslimah. (2020). Peningkatan Hasil Belajar IPS Melalui Model Pembelajaran Problem Based Learning Kelas IXD SMP Negeri 1 Tawangsari. Jurnal Pendidikan, Volume 29(3), Nopember 2020, hal: 287-294.

Nurdianto Talqis, dan Noor Azizi Bin Ismail. (2020). Pembelajaran Bahasa Arab Berbasis Common European Framework Of Reference For Language (CEFR) Di Indonesia. Jurnal at-Mahara: Jurnal Pendidikan Bahasa Arab, volume 6(1), Juni.

Petta Solong, Najamuddin, dan Luki Husin. (2020). Penerapan Kompetensi Kepribadian Guru Pai. Ta'dibuna: Jurnal Pendidikan Agama Islam 3.2.

Perdana Ayusi Putri, dkk. (2021). Strategi Pembelajaran Melalui Daring dan Luring Selama Pandemi Covid-19 di SD Negeri Sugihan 03 Bendosari. Prima Magistra: Jurnal Ilmiah Pendidikan volume 2(1), April.

Putria, Hilnadkk. (2020). Analisis Proses Pembelajaran Dalam jaringan (Daring) Masa Pandemi Covid-19 Pada Guru Sekolah Dasar, Jurnal Basicedu, volume 4(4).

Roni, Acep Hamdani, dan Asep Priatna, (2020). Efektivitas Implementasi Pembelajaran Daring (Full Online) Dimasa Pandemi Covid-19 Pada Jenjang Sekolah Dasar di Kabupaten Subang, Jurnal Ilmiah PGSD SKTKIP Subang volume 6(1), Juni.

Rosita Novi Rahmawati, dkk. (2020). Analisis Pembelajaran Daring Saat Pandemi di Madrasah Ibtidaiyah, SITTAH: Journal of Primary Education, volume 1(2), Oktober.

Trisnawati Wahyu dan Sugito. (2021).Pendidikan Anak Dalam Keluarga Era Covid-19, Jurnal Obsesi: Jurnal Pendidikan Anak Usia Dini, volume 5(1).

Wahida, Robbiatul. (2020). Penilaian Sikap Tanggung Jawab Pada Pembelajaran Bahasa Arab Daring Via WhatsApp Di Madrasah Tsanawiyah, Jurnal Sastra Arab: Prosiding Konferensi Nasional Bahasa Arab VI Malang, 04 Oktober.

Wahyono, Poncojari dkk. (2020). Guru Profesional di masa Pandemi Covid-19: Review Implementasi, Tantangan, dan Solusi Pembelajaran Daring, Jurnal Pendidikan Profesi Guru volume 1(1).

Wardani Anita dan YuliaAyriza. (2021). Analisis Kendala Orang Tua dalam Mendampingi Anak Belajar Di Rumah Pada Masa Pandemi Covid-19. Jurnal Obsesi: Jurnal Pendidikan Anak Usia Dini volume 5(1).

Wahyuni, Sri. (2020). Upaya Meningkatkan Prestasi Belajar IPS Melalui Metode Pembelajaran Kooperatif Tipe STAD Pada Siswa Kelas IX A SMP Negeri 2 Sukoharjo Semester I Tahun Pelajaran 2019/2020.Jurnal Pendidikan, volume 29(3), Nopember 2020, hal: 269-278. 